\author{
Biloshkurska $\mathbf{N}$. \\ Biloshkurskyi M., \\ Chyrva H.
}

\section{ESTIMATED LOSSES OF INNOVATIVE CAPACITY OF THE PARTIES AS A RESULT OF «HYBRID» RUSSIAN AGGRESSION AGAINST UKRAINE}

Об’єктом дослідження є процес оцінки втрат інноваційного потенціалу держав, що перебувають у стані «гібридного» військового протистояння. Проте, виникає проблема достовірності результатів такої оцінки. Цього можливо досягти шляхом порівняння відхилень фактичної динаміки результатів національного виробництва з урахуванням факторів фізичного та людського капіталу, а також технологічного прогресу.

У роботі проведено оцінку втрат (приросту) інноваційного потениіалу України як держави-жертви та Росії як держави-агресора у «гібридній» війні, що розпочалася з тимчасової окупачії Автономної республіки Крим і триває донині. В основу результатів очінки покладено реальні (офічійні) статистичні дані Світового Банку, наявні у публічному доступі за 1995-2017 рр. Об’єктом оцінки є динаміка результатів національних економік сторін конфлікту з урахуванням виробничих факторів і технологічного прогресу.

Реалізовано вдосконалення методичного забезпечення оцінки втрат інновачійного потенщіалу на макрорівні шляхом моделювання виробничої функиї Тінбергена-Солоу. В результаті чого отримано фіксовану і поточну динаміку параметра технологічного прогресу для держав-антагоністів у «гібридному» конфлікті за 2013-2017 рр. Розраховано різнищі множників виробничої функиї Тінбергена-Солоу з параметром технологічного прогресу - фіксованого за 2013 рік і поточного за 2014-2017 роки.

Обгрунтовано, що протягом 4 років «гібридної» агресії відновлення національної економіки України відбувається на 7,5\% повільніше, ніж Росіі. Приріст інновачійного потениіалу України у період $2014-$ 2017 рр. склав 2,1\% обсягу ВВП на кінець 2013 року. Втрати інноваційного потенціалу Росії за ией же період становили 8,5\% обсягу ВВП 2013 року.

Результати вдосконалення методичного забезпечення процесу оцінки втрат інноваційного потенціалу сторін «гібридної» агресії закладають основу для моделювання динаміки реального ВВП та його фізичного обсягу, що значно розширить базу майбутніх досліджень.

Ключові слова: інновачійний потениіал, виробнича функиія, макроекономічна динаміка, «гібридна» агресія, ВВП у фактичних иінах.

\section{Introduction}

Having started from 20 of February of 2014 and till today, the Ukrainian national economy develops under conditions of Russian «hybrid» aggression that creates essential obstacles for its real growth. Under conditions of the modern globalized society the formation of effective contra-arrangements by Ukraine (both internal and external ones) is impossible without most developed countries and international associations. As a result - both the victim and the aggressor suffer from real and potential losses. So, there appears a necessity of the qualitative and quantitative estimation of innovation potential losses of the parties as a result of «hybrid» aggression of Russia against Ukraine.

\section{The object of research and its technological audit}

The object of the research is the process of estimation of losses of the innovation potential of the states that are in «hybrid» military confrontation.

There appears a necessity of the effective and reliable audit of losses of the innovative potential of both the state-victim and the state-aggressor under conditions of the «hybrid» conflict. It may be achieved by checking deviations of the real dynamics of gross domestic product (GDP) taking into account factors of physical and human capital and also technological progress. At that the base assumption is that the innovative potential of the conflicting parties will be lost as a result of their lag from the technological progress - the victim faster and in more volumes than the aggressor. The calculation of innovation potential losses is offered to measure in \% of GDP.

\section{The aim and objectives of research}

The aim of the research - elaboration of a methodical approach to estimation of innovation potential losses of the conflicting parties as a result of Russian «hybrid» aggression against Ukraine taking into account the factor of technological progress.

The following scientific tasks were set for attaining this aim:

1. To elaborate main requirements that must be realized at estimating losses (increment) of the innovation potential of the states - parties of «hybrid» aggression.

2. To offer an economic-mathematical model that will satisfy set requirements as completely as possible. 
3. To study the dynamics of the technological progress parameter of the states-antagonists in the «hybrid» conflict for 2013-2017.

4. To estimate volumes of losses of the innovation potential of the states - parties of «hybrid» aggression.

\section{Research of existing solutions of the problem}

Many scientists and practicians study economic and social problems of the Russian «hybrid» war against Ukraine. Work [1], prepared by specialists of the National institute of strategic studies for the first time studies a phenomenon of World «hybrid» war in the perspective of Russian aggression against Ukraine in detail. Work [2] separates and explains important theoretical methodological and adjacent ideological questions of further elaboration of the system of Ukrainian national safety under conditions of external aggression and loss of a part of the state territory. Work [3] grounds priorities of the development of the real sector of the Ukrainian economy in 2016-2017 under conditions of the exhaustive confrontation between Ukraine and Russian Federation in the «hybrid» war. Work [4] analyzes diverse aspects of modern hybrid wars, interpreting the meaning of information confrontation with an accent on Russian hybrid aggression against Ukraine. Work [5] considers Russian military aggression as a stress-test for global and national safety and catalyzer of rebooting of the Ukrainian external policy.

Study [6] is devoted to lessons, obtained by Europe during the war in Ukraine, especially safety ones, economic and politic. Theoretical and applied aspects of the Russian «hybrid» war that is an asymmetric conflict are considered in work [7] Scientific work [8] starts debates about hybrid war in the wider analytic and historical context, and also generalizes a discussion about asymmetric strategic conceptions. Work [9] studies the development of the Russian military strategy and how its elements may be used in Ukraine. Study [10] proves that «hybrid» challenges and threats must widen the Asian and European interest for international cooperation, especially by accepting correspondent conceptions of safety and power instruments. The geopolitical distribution of forces the day before and at the first year of the «hybrid» war, and also possible confrontations between NATO, Russia and Ukraine are considered in [11]. Work [12] grounds that a tendency to «hybrid» war is not only for conceptualization of the development of the Russian military and external policy; it may result in serious unpredictable consequences for the whole world. Works [13-15] make a detail analysis of a role of the European union and causes of Russian hybrid aggression against Ukraine, in which result the Crimean Autonomous republic was occupied and military actions at Donbas were started.

But the problem of functioning of the methodical support of estimating innovation potential losses of the parties as a result of Russian «hybrid» aggression against Ukraine, started in [16-18], remains little-studied, so needs substantial studies; because under modern conditions just the macroeconomic development on innovative bases becomes a key factor of overcoming war results.

\section{Research methods}

General scientific and special research methods were used at the work:
- analysis and synthesis - for the preliminary analysis with forming a problem, determination of aims, main assumptions and requirements to estimation of innovation potential losses of the parties as a result of Russian «hybrid» aggression against Ukraine; - analogues and comparative collation - for determining main characteristics of the countries-antagonists in «hybrid» aggression and for elaborating criteria for estimating innovation potential losses;

- method of correlation-regression analysis - for formalizing the influence of base speeds of the growth of gross fixed capital formation and the number of employed population, and also dynamic component on the dynamics of GDP in real prices;

- method of factor analysis - for calculating volumes of innovation potential losses of the states taking into account the technological progress factor.

\section{Research results}

Under modern conditions the technological progress is a key factor of forming the innovation potential of the national economy. So, there appears a necessity to take into account its influence on the dynamics of GDP of a state. The crucial value at improving the methodical support for estimating innovation potential losses of the parties as a result of Russian «hybrid» aggression against Ukraine is to take into account correspondence of their national economies to the technological progress. It is understood as an objective factor of the macroeconomic development on innovative principles [18].

Main methodological bases of estimating the technological progress are given in works [19-21]. Ideas about estimating the innovative potential of the national economy remain important for today. But scientists-economists have yet insufficiently studied problems of estimating innovation potential losses of the state-victim and state-aggressor under conditions of «hybrid» war.

Realization of the reliable estimation of innovation potential losses of the state is possible only at observing a series of requirements:

- methodical support of such estimation must be based on real (official) statistical data, accessible freely [16]; - studies must include an essential time lag, no less

10 years and to reflect the dynamics [22];

- an estimation object must be a subject of the innovation process at the same time [18].

Correspondence to all requirements to the methodical support of estimating the innovation potential of the state, including its losses, is provided by the multiplicative dynamic economic-mathematical model of the production function, offered by the authors of works [23, 24], that in the research context looks as:

$G D P=A \cdot G F C F^{\alpha} \cdot N E^{\beta} \cdot e^{\gamma t}$,

where GDP - basis speed of GDP growth of the state in real prices (in \% to the index of the first year of the dynamics); $G F C F$ - physical capital factor - basis growth speed of gross fixed capital formation, \%;

$N E$ - human capital factor - basis growth speed of the number of whole employed population, \%;

parameter $A$ - free member (numerical value of $G D P$, if $\alpha=\beta=\gamma=0$ ); 
parameter $\alpha$ - elasticity coefficient of GDP by the physical capital factor (by what \% GDP increases at growing GFCF by $1 \%$ );

parameter $\beta$ - elasticity coefficient of GDP by the human capital factor (by what \% GDP increases at growing $N E$ by $1 \%$ ), at that $\beta=1-\alpha$;

parameter $\gamma$ - technological progress parameter - elasticity coefficient of GDP by the technological progress;

$e$ - Euler number (natural logarithm base);

$t$ - technological progress factor (year sequence number).

In formula (1) a multiplier $e^{\gamma t}$ is the most suitable for estimating losses or increment of the state innovative potential, it reflects the influence of the technological progress on GDP dynamics as following:

- when $\gamma=0, e^{\gamma t}=1$, and formula (1) looks as the two-factor multiplicative production function of Cobb-Douglas [25]. Then it is possible to talk about the neutral influence of the technological progress or simple recreation, because Cobb-Douglas production function is one with the constant return from the production volume. In this case the summary growth of factors of physical and human capitals by $1 \%$ results in growing GDP by $1 \%$;

- when $\gamma<0, e^{\gamma t}<1$. It means that as a result of lagging from the technological progress, the state suffers from innovation potential losses $\left(e^{\gamma t}-1\right) \%$ of GDP. So, the summary growth of factors of physical and human capitals by $1 \%$ results in growing GDP less than by $1 \%$; - when $\gamma>0, e^{\gamma t}>1$. It means that as a result of correspondence of the national economy to the technological progress, the state gains the additional increment of the innovative potential $\left(e^{\gamma t}-1\right) \%$ of GDP. In this case the summary growth of factors of physical and human capitals by $1 \%$ results in growing GDP more than by $1 \%$.

For the further use in modeling, let's sign formula (1) in the logarithm form, having expressed the parameter $\beta$ by $(1-\alpha)$ :

$$
\ln G D P=\ln A+\alpha \ln G F C F+(1-\alpha) \ln N E+\gamma t .
$$

Having analyzed a series of algebraic transformations as it is suitable for modeling the dependence of GDP on the technological progress, let's sign Tinbergen-Solow function as follows [26]:

$$
\ln G D P-\ln N E=\ln A+\alpha(\ln G F C F-\ln N E)+\gamma t .
$$

Losses or increment of the innovative potential of the national economies of the states - parties of the «hybrid» conflict are calculated, according to formula (3). This formula helps to find values of the technological progress parameter $\gamma$ for each year of the confrontation, and it is compared with the year before military actions.

Then there is calculated the numerical value of the expression $e^{\gamma t}$ for finding GDP increment, which negative value testifies to innovation potential losses of the states-antagonists as a result of «hybrid» aggression.

Based on given formulas (1)-(3), let's form the initial data for the state-victim of «hybrid» aggression - Ukraine in Table 1, for the state-aggressor - Russia - in Table 2.

\begin{tabular}{|c|c|c|c|c|c|c|}
\hline \multirow{2}{*}{ Years } & \multicolumn{2}{|c|}{ GDP in real prices $(G D P)$} & \multicolumn{2}{|c|}{ Gross fixed capital formation (GFCF) } & \multicolumn{2}{|c|}{ Number employed population (NE) } \\
\hline & Mln USD & in \% to 1995 & Mln USD & in \% to 1995 & Thousand persons & in \% to 1995 \\
\hline 1995 & 48213.9 & 100.0 & 11224.3 & 100.0 & 24125.1 & 100.0 \\
\hline 1996 & 44558.1 & 92.4 & 9232.6 & 82.3 & 24114.0 & 100.0 \\
\hline 1997 & 50150.4 & 104.0 & 9946.3 & 88.6 & 23755.5 & 98.5 \\
\hline 1998 & 41883.2 & 86.9 & 8204.1 & 73.1 & 22998.4 & 95.3 \\
\hline 1999 & 31580.6 & 65.5 & 6084.3 & 54.2 & 19947.8 & 82.7 \\
\hline 2000 & 31261.5 & 64.8 & 6144.4 & 54.7 & 20175.0 & 83.6 \\
\hline 2001 & 38009.3 & 78.8 & 7485.2 & 66.7 & 19971.5 & 82.8 \\
\hline 2002 & 42392.9 & 87.9 & 8126.9 & 72.4 & 20091.2 & 83.3 \\
\hline 2003 & 50133.0 & 104.0 & 10327.8 & 92.0 & 20163.3 & 83.6 \\
\hline 2004 & 64883.1 & 134.6 & 14630.6 & 130.3 & 20295.7 & 84.1 \\
\hline 2005 & 86142.0 & 178.7 & 18921.1 & 168.6 & 20680.0 & 85.7 \\
\hline 2006 & 107753.1 & 223.5 & 26509.7 & 236.2 & 20730.4 & 85.9 \\
\hline 2007 & 142719.0 & 296.0 & 38649.3 & 344.3 & 20904.7 & 86.7 \\
\hline 2008 & 179992.4 & 373.3 & 47493.5 & 423.1 & 20972.3 & 86.9 \\
\hline 2009 & 117227.8 & 243.1 & 21517.1 & 191.7 & 20191.5 & 83.7 \\
\hline 2010 & 136013.2 & 282.1 & 23169.9 & 206.4 & 20266.0 & 84.0 \\
\hline 2011 & 163159.7 & 338.4 & 28792.0 & 256.5 & 20324.2 & 84.2 \\
\hline 2012 & 175781.4 & 364.6 & 33386.9 & 297.5 & 20354.4 & 84.4 \\
\hline 2013 & 183310.1 & 380.2 & 30908.8 & 275.4 & 20404.1 & 84.6 \\
\hline 2014 & 133503.4 & 276.9 & 18872.1 & 168.1 & 18073.3 & 74.9 \\
\hline 2015 & 91031.0 & 188.8 & 12333.5 & 109.9 & 16443.2 & 68.2 \\
\hline 2016 & 93270.5 & 193.5 & 14129.6 & 125.9 & 16276.9 & 67.5 \\
\hline 2017 & 112154.0 & 232.6 & 17949.1 & 159.9 & 16156.4 & 67.0 \\
\hline
\end{tabular}

Initial data of modeling of Tinbergen-Solow production function for Ukraine in 1995-2017

Note: formed and calculated by data, given in [27] 
The data, given in table 1 , demonstrate that in the last 23 years Ukrainian GDP in real prices, calculated in USA dollars, grew annually in average by $+3.7 \%$. At that having achieved the least value 31.3 bil USD in 2000 year, and the biggest one - 183.3 bil USD - in 2013. The calculated dynamics of GDP was accompanied by the average annual increment of gross fixed capital formation $+2.1 \%$ and annual average reduction of the number of employed population $-1.7 \%$.

The data, given in table 1 , demonstrate that in the last 23 years Russian GDP in real prices, calculated in USA dollars, grew annually in average by $+6.2 \%$. At that having achieved the least value 195.9 USD in 1999 year, and the biggest one - 2297.1 bil USD - in 2013 . The calculated dynamics of GDP was accompanied by the average annual increment of the gross fixed capital formation $+6.3 \%$ and the number of employed population of Russia $+0.5 \%$.

It must be also noted, that in 2015 comparing with 2014 GDP volume of Ukraine in real prices of USD decreased by $-31.8 \%$, and Russia - by $-33.8 \%$. Thus, we can make a conclusion that the results of «hybrid» aggression for Russia in 2015 were worse than for Ukraine, because its GDP reduction was by $2 \%$ more.

According to the initial data, collected in Tables 1, 2, using formula (3), there were successively realized 5 iterations of modeling of Tinbergen-Solow function for Ukraine and Russia, as a result of which, there were obtained the correspondent parameters of the equations for 2013-2017 (Table 3).
Table 3

Results of modeling of Tinbergen-Solow production function for the states-antagonists of «hybrid» aggression

\begin{tabular}{|c|c|c|c|c|c|c|}
\hline $\begin{array}{c}\text { Parameter } \\
\text { of function* }\end{array}$ & $\begin{array}{c}2013 \\
\text { year }\end{array}$ & $\begin{array}{c}2014 \\
\text { year }\end{array}$ & $\begin{array}{c}2015 \\
\text { year }\end{array}$ & $\begin{array}{c}2016 \\
\text { year }\end{array}$ & $\begin{array}{c}2017 \\
\text { year }\end{array}$ & $\begin{array}{c}\text { Changes (+/-) in } \\
\text { 2017 comparing } \\
\text { with 2013 }\end{array}$ \\
\hline \multicolumn{7}{|c|}{ Ukraine } \\
\hline A & 0.896 & 0.876 & 0.884 & 0.901 & 0.913 & +0.017 \\
\hline$\alpha$ & 0.683 & 0.660 & 0.670 & 0.692 & 0.702 & +0.019 \\
\hline$\beta$ & 0.317 & 0.340 & 0.330 & 0.308 & 0.298 & -0.019 \\
\hline$M^{\prime} 5^{* *}$ & -2.155 & -1.941 & -2.030 & -2.247 & -2.356 & -0.201 \\
\hline$\gamma$ & 0.038 & 0.042 & 0.040 & 0.037 & 0.035 & -0.003 \\
\hline$R^{2 * * *}$ & 0.987 & 0.986 & 0.987 & 0.985 & 0.985 & -0.002 \\
\hline \multicolumn{7}{|c|}{} \\
\hline A & 1.034 & 1.036 & 1.058 & 1.080 & 1.092 & +0.058 \\
\hline$\alpha$ & 0.801 & 0.801 & 0.817 & 0.832 & 0.839 & +0.038 \\
\hline$\beta$ & 0.199 & 0.199 & 0.183 & 0.168 & 0.161 & -0.038 \\
\hline$M R T 5$ & -4.025 & -4.025 & -4.464 & -4.952 & -5.211 & -1.186 \\
\hline$\gamma$ & 0.014 & 0.014 & 0.011 & 0.008 & 0.006 & -0.008 \\
\hline$R^{2}$ & 0.996 & 0.996 & 0.996 & 0.995 & 0.995 & -0.001 \\
\hline
\end{tabular}

Note: ${ }^{*}$ - symbols of parameters are taken from formula (1); ${ }^{* *}$ maximal rate of technological substitution: $M R T S=-\frac{\alpha N E}{\beta G F C F} ;{ }^{* * *}-H^{2}-$ coefficient of plural determination that demonstrates for how much percent the substitution of the resulting sign is conditioned by the change of factor signs, interprets the reliability of formalization

Table 2

Initial data of modeling of Tinbergen-Solow production function for Russia in 1995-2017

\begin{tabular}{|c|c|c|c|c|c|c|}
\hline \multirow{2}{*}{ Years } & \multicolumn{2}{|c|}{ GDP in real prices (GDP) } & \multicolumn{2}{|c|}{ Gross fixed capital formation (GFCF) } & \multicolumn{2}{|c|}{ Number employed population (NE) } \\
\hline & Mln USD & in \% to 1995 & Mln USD & in \% to 1995 & Thousand persons & in \% to 1995 \\
\hline 1995 & 395531.1 & 100.0 & 83370.3 & 100.0 & 64149.0 & 100.0 \\
\hline 1996 & 391720.0 & 99.0 & 78351.8 & 94.0 & 62928.0 & 98.1 \\
\hline 1997 & 404926.5 & 102.4 & 74070.9 & 88.9 & 60021.0 & 93.6 \\
\hline 1998 & 270953.1 & 68.5 & 43760.9 & 52.5 & 58437.0 & 91.1 \\
\hline 1999 & 195905.8 & 49.5 & 28184.4 & 33.8 & 63082.0 & 98.3 \\
\hline 2000 & 259708.5 & 65.7 & 43796.7 & 52.5 & 65070.4 & 101.4 \\
\hline 2001 & 306602.7 & 77.5 & 57912.2 & 69.5 & 65122.9 & 101.5 \\
\hline 2002 & 345110.4 & 87.3 & 61860.1 & 74.2 & 66658.9 & 103.9 \\
\hline 2003 & 430347.8 & 108.8 & 79248.7 & 95.1 & 66339.4 & 103.4 \\
\hline 2004 & 591016.7 & 149.4 & 108660.2 & 130.3 & 67318.6 & 104.9 \\
\hline 2005 & 764017.1 & 193.2 & 135654.3 & 162.7 & 68339.0 & 106.5 \\
\hline 2006 & 989930.5 & 250.3 & 183170.9 & 219.7 & 69168.7 & 107.8 \\
\hline 2007 & 1299705.0 & 328.6 & 272876.5 & 327.3 & 70770.3 & 110.3 \\
\hline 2008 & 1660844.0 & 419.9 & 370210.2 & 444.1 & 71003.1 & 110.7 \\
\hline 2009 & 1222644.0 & 309.1 & 268922.3 & 322.6 & 69410.5 & 108.2 \\
\hline 2010 & 1524916.0 & 385.5 & 329769.2 & 395.6 & 69933.7 & 109.0 \\
\hline 2011 & 2051662.0 & 518.7 & 440843.7 & 528.8 & 70856.6 & 110.5 \\
\hline 2012 & 2210257.0 & 558.8 & 476306.6 & 571.3 & 71545.4 & 111.5 \\
\hline 2013 & 2297128.0 & 580.8 & 500221.4 & 600.0 & 71391.5 & 111.3 \\
\hline 2014 & 2063663.0 & 521.7 & 438480.8 & 525.9 & 71539.0 & 111.5 \\
\hline 2015 & 1365864.0 & 345.3 & 283341.8 & 339.9 & 72323.6 & 112.7 \\
\hline 2016 & 1283163.0 & 324.4 & 270109.0 & 324.0 & 72392.6 & 112.9 \\
\hline 2017 & 1577524.0 & 398.8 & 342228.1 & 410.5 & 72315.9 & 112.7 \\
\hline
\end{tabular}

Note: formed and calculated by data, given in [27] 
The data of Table 3 reflect GDP dynamics in real prices (mln USD) taking into account proportions of the physical and human capitals and also correspondences of the national economy to the technological progress of Ukraine as a country-victim and Russia as a country-aggressor under conditions of the «hybrid» conflict. As a result of modeling there were obtained 5 equations of Tinbergen-Solow production function as a result of realized iterations as follows:

- the first iteration in modeling is realized according to official statistic data of the World bank [27] for1995-2013, obtained values of the technological progress parameter are taken as base ones, because 2013 is the last one before «hybrid» aggression;

- the second iteration is realized by adding the previous volume (for 1995-2013) to the data for 2014 (first year of «hybrid» aggression - occupation of the Autonomous Crimean Republic and separate territories of the Donetsk and Lugansk regions). As a result of modeling, there are obtained new values of the technological progress parameter;

- the third, fourth and fifth iterations are realized analogously with the first-turn addition of official statistic data to the existent volume for the next year and modeling of the indicated production function for obtaining the numerical technological progress parameter.

The obtained results of modeling Tinbergen-Solow production function for each of 2013-2017 years for Ukraine and Russia, given in Table 3, allow to make a series of important conclusions. All obtained equations are statistically important, because values of correspondent coefficient of plural determination are $R^{2}>0.9$. The structure of the influence of production factors on GDP formed in the national economy of Ukraine:

- for the end of 2013 the physical capital influence was $68 \%$, human one $-32 \%$. That is human capital losses for compensating the decrease for 1 unit of the physical capital are 2.2 times more;

- for the end of 2017 the physical capital influence was $70 \%$, human one $-30 \%$. That is human capital losses for compensating the decrease for 1 unit of the physical capital are already 2.4 times more.

In the Russian national economy:

- for the end of 2013 the physical capital influence was $80 \%$, human one $-20 \%$. That is human capital losses for compensating the decrease for 1 unit of the physical capital are 4 times more;

- for the end of 2013 the physical capital influence increased to $84 \%$, human one correspondingly decreased to $16 \%$. That is human capital losses for compensating the decrease for 1 unit of the physical capital are already 5.2 times more.

Another typical result of the study is the observed reduction dynamics of the technological progress parameter of the studied countries ( -0.003 for Ukraine and -0.008 for Russia), that is a direct result of «hybrid» aggression. Thus, the process of the «hybrid» conflict causes innovative potential losses of the national economy of both country-victim and country-aggressor, so domination of the physical capital in the national economy grows. So, there appears a necessity of the complex estimation of volumes of losses (increment) of the innovative potential of the states-parties of «hybrid» aggression. For that it is necessary to make calculations of the multiplier of
Tinbergen-Solow production function that includes the technological progress parameter (Table 4).

Table 4

Calculations of losses (increment) of the innovative potential of the national economies of the states-antagonists of «hybrid» aggression in 2013-2017

\begin{tabular}{|c|c|c|c|c|c|c|}
\hline \multirow{2}{*}{$\begin{array}{l}\text { Calculating } \\
\text { parameter * }\end{array}$} & \multicolumn{5}{|c|}{ Values of parameter by years } & \multirow{2}{*}{ Totally } \\
\hline & 2013 & 2014 & 2015 & 2016 & 2017 & \\
\hline \multicolumn{7}{|c|}{ Ukraine } \\
\hline$e^{\gamma_{i} t_{i}} * *$ & 2.064 & 2.307 & 2.336 & 2.272 & 2.256 & $\mathrm{x}$ \\
\hline$e^{\gamma_{2013} t_{i}}$ & 2.064 & 2.144 & 2.228 & 2.314 & 2.404 & $\mathrm{x}$ \\
\hline$e^{\gamma_{i} t_{i}}-e^{\gamma_{2013} t_{i}}$ & 0 & +0.163 & +0.108 & -0.042 & -0.148 & +0.081 \\
\hline $\begin{array}{c}\text { Increment } \\
(+) \text { Losses } \\
(-) \text { of the } \\
\text { innovative } \\
\text { potential of } \\
\text { the national } \\
\text { economy, } \\
\text { mln USD }\end{array}$ & 0 & +7858.9 & +5207.1 & -2025.0 & -7135.7 & +3905.3 \\
\hline \multicolumn{7}{|c|}{ Russia } \\
\hline$e^{\gamma_{i} t_{i}}$ & 1.305 & 1.316 & 1.253 & 1.188 & 1.156 & $x$ \\
\hline$e^{\gamma_{2013} t_{i}}$ & 1.305 & 1.323 & 1.342 & 1.360 & 1.380 & $\mathrm{x}$ \\
\hline$e^{\gamma_{i} t_{i}}-e^{\gamma_{2013} t_{i}}$ & 0 & -0.007 & -0.089 & -0.172 & -0.224 & -0.492 \\
\hline $\begin{array}{l}\text { Increment } \\
(+) \text { Losses } \\
(-) \text { of the } \\
\text { innovative } \\
\text { potential of } \\
\text { the national } \\
\text { economy, } \\
\text { mln USD }\end{array}$ & 0 & -2768.7 & -35202.3 & -68031.3 & -88599.0 & -194601.3 \\
\hline
\end{tabular}

In Table 4 annual losses (increments) of the innovative potential of the national economy of Ukraine $\left(\Delta I P U_{i}\right)$ were calculated by formula:

$$
\Delta I P U_{i}=48213.9\left(e^{\gamma_{i} t_{i}}-e^{\gamma_{2013} t_{i}}\right),
$$

where 48213.9 - volume of base GDP of Ukraine in real prices of 1995, mln USD; $\gamma_{i}$ - technological progress parameter of $i$-year, $i \in[2013 ; 2017] ; t_{i}$ - successive number of $i$-year, $i \in[2013 ; 2017]$.

Annual losses (increments) of the innovative potential of the national economy of Russia $\left(\triangle I P R_{i}\right)$ were calculated by formula:

$$
\Delta I P R_{i}=395531.1\left(e^{\gamma_{i} t_{i}}-e^{\gamma_{2013} t_{i}}\right),
$$

where 395531.1 - volume of base GDP of Russia in real prices of 1995, mln USD.

Thus, the summary increment of the innovative potential of Ukraine (country-victim of «hybrid» aggression) in 2014-2017 was +3.9 bil USD or $2.1 \%$ of GDP volume in real prices of 2013. In general, it indicates the presence of widened recreation of the Ukrainian national economy by increasing production volumes in the military-industrial complex and other adjacent economic spheres, effectiveness of the macroeconomic help, increase of volumes of capi- 
tal investments in material production and so on. These positive arrangements were realized under conditions of the «hybrid» conflict, temporal occupation of the Crimean Autonomous Republic and parts of the Donetsk and Lugansk regions, real economic decline, inflation in whole and growth of prices for energy sources in particular; devaluation of the national monetary unit and so on. But in 2017 Ukrainian GDP in real prices (mln USD was only $61.2 \%$ of the pre-conflict level of 2013 .

According to the data of Table 4, summary losses of the Russian innovative potential in the period of 2014-2017 were 194.6 bil USD or $8.5 \%$ of GDP volume in real prices of 2013. The country-aggressor in the «hybrid» conflict suffers from essential losses, mainly because of international economic sanctions, external economic isolation of key economic spheres and negative price dynamics of oil as a main GDP-creating resource. In 2017 Russian GDP in real prices (mln USD) was only $68.7 \%$ of the pre-conflict level of 2013. It means that renovation of the national economy of the country-aggressor is faster (by $7.5 \%$ ), comparing with the country-victim, but with essential innovative potential losses.

\section{SWOT analysis of research results}

Strengths. Strengths of the research as to using the model of Tinbergen-Solow production function are in fact that the dynamics of the technological process parameter allows to estimate volumes of innovative potential losses of the parties of «hybrid» aggression - both country-victim and country-aggressor.

Weaknesses. Weaknesses of the conducted research may be considered as the fact that the estimation results, obtained using the offered methodological approach are not complete, although they are based only on modeling the base GDP dynamics taking into account three factors - base growth rates of the physical and human capital and technological progress. At that any other factors are neglected.

Opportunities. It must be noted that in further the process of estimation of innovative potential losses of the conflict parties may be considered as a base of setting and solving the wide spectrum of optimization problems, connected with Ukrainian GDP maximization under conditions of «hybrid» aggression. It will be the base for further studies.

Threats. Threats of estimation of innovative potential losses of the parties as a result of «hybrid» aggression of Russia against Ukraine include the fact that the offered methodical approach cannot be considered as a means that allows to provide a base for making managerial decisions at the international level The estimation process is complicated by the objective impossibility to classify and detail existent losses concretely by types.

\section{Conclusions}

1. The work realizes an attempt to estimate losses (increment) of the innovative potential of Ukraine as a state-victim and Russia as a state-aggressor in the «hybrid» war, started from 20 of February of 2014 from the temporary occupation of the Crimean Autonomous Republic and continuing till today. It was grounded, that the estimation reliability is provided at the expanse of using real (official) statistic data for the period of more than 10 years and an estimation object must be at the same time a subject of the innovative process.

2. There was improved the methodical support of estimating innovative potential losses at the macrolevel by probating Tinbergen-Solow production function and studying the dynamics of the technological progress parameter for the states-antagonists in the «hybrid» conflict for 2013-2017. There were conducted 5 iterations of the model for the studied countries and calculated the differences of multipliers of Tinbergen-Solow production function, including the values of the technological progress parameter - fixed for 2013 and current for 2014-2017.

3. There was studied the dynamics of the technological progress parameter for the states-antagonists in the «hybrid» conflict for 2013-2017. The technological progress parameter, obtained for the national economy of Ukraine in 2013 before the aggression was 0.038. At the expanse of the existent innovative potential it increased in 2014 by +0.004 . For the end of 2017 its value for the country-victim decreased by-0.007, comparing with 2014. The numerical value of the technological progress parameter, obtained for the national economy of Russia at the end of 2013 was 0.014 . It remained at the same level in 2014 at the expanse of the existent innovative potential. The general decline of the technological progress parameter for Russia for the period of «hybrid» confrontation was -0.008 .

4. It was proved that during 4 years of «hybrid» aggression the renovation of the national economy of Ukraine is slower than in Russia by $7.5 \%$. But the summary increment of the Ukrainian innovative potential in 2014-2017 was +3.9 bil USD or $2.1 \%$ of the GDP volume in real prices for the end of 2013. Russian innovative potential losses for the same period were -194.6 bil USD or $8.5 \%$ of the GDP volume of 2013. The offered methodical approach to estimating innovative potential losses of thee parties of «hybrid» aggression will be further probated for the dynamics of real GDP and its physical volume, and will be further investigations of the authors in this direction.

\section{Acknowledgements}

The research was publicly funded by Ministry of Education and Science of Ukraine for developing of research project No. 0117U003855 «Institutional and technological design of innovation networks for Ukraine national security systemic providing».

\section{References}

1. Horbulin V. The World Hybrid War: Ukrainian Forefront: monograph. Kharkiv: Folio, 2017. 158 p.

2. Vlasiuk O. S., Kononenko S. V. Kremlivska ahresiia proty Ukrainy: rozdumy v konteksti viiny: monograph. Kyiv: NISD, 2017. 304 p.

3. Realnyi sektor ekonomiky Ukrainy: priorytety rozvytku v umovakh zminy vektora ekonomichnoi polityky: analit. dop. / Sobkevych O. V. et. al. Kyiv: NISD, 2017. 40 p.

4. Hibrydna viina: in verbo et in praxi: monograph / ed. by Dodonov R. O. Vinnytsia: TOV «NilanLTD», 2017. 412 p.

5. Donbas i Krym: tsina povernennia: monograph / ed. by Horbulin V. P. et. al. Kyiv: NISD, 2015. 474 p.

6. The War in Ukraine: Lessons for Europe / Antonenko A. et. al. Riga, 2015. 182 p.

7. Banasik M. Russia's Hybrid War in Theory and Practice // Journal on Baltic Security. 2016. Vol. 2, Issue 1. P. 157-182. doi: http://doi.org/10.1515/jobs-2016-0035 
8. Wither J. K. Making Sense of Hybrid Warfare // Connections: The Quarterly Journal. 2016. Vol. 15, Issue 2. P. 73-87. doi: http://doi.org/10.11610/connections.15.2.06

9. Thomas T. Russia's Military Strategy and Ukraine: Indirect, Asymmetric - and Putin-Led. The Journal of Slavic Military Studies. 2015. Vol. 28, Issue 3. P. 445-461. doi: http://doi.org/ 10.1080/13518046.2015.1061819

10. Thiele R. D. Crisis in Ukraine - the emergence of hybrid warfare // ISPSW Strategy Series: Focus on Defense and International Security. 2015. Issue 347. P. 1-13.

11. Charap S. The Ghost of Hybrid War // Survival. 2015. Vol. 57, Issue 6. P. 51-58. doi: http://doi.org/10.1080/00396338.20 15.1116147

12. Renz B. Russia and "hybrid warfare." // Contemporary Politics. 2016. Vol. 22, Issue 3: Russia, the West, and the Ukraine Crisis. P. 283-300. doi: http://doi.org/10.1080/13569775.2016.1201316

13. Petro N. N. Ukraine in crisis. European Politics and Society. 2016. Vol. 17, Issue 4. P. 421-423. doi: http://doi.org/10.1080/ 23745118.2016 .1154128

14. Gardner H. The Russian annexation of Crimea: regional and global ramifications // European Politics and Society. 2016. Vol. 17, Issue 4. P. 490-505. doi: http://doi.org/10.1080/23 745118.2016.1154190

15. Kuzio T. Ukraine between a Constrained EU and Assertive Russia // JCMS: Journal of Common Market Studies. 2016. Vol. 55, Issue 1: Special Issue: Europe's Hybrid Foreign Policy: The Ukraine-Russia Crisis. P. 103-120. doi: http://doi.org/ 10.1111/jcms.12447

16. Biloshkurskyi M. V. Do problemy ekonomichnoi diahnostyky stanu rozvytku innovatsiinoi diialnosti pidpryiemstv: proceedings // Sotsialno-ekonomichni transformatsii v umovakh hlobalizatsii: svitovyi ta vitchyznianyi vymiry / ed. by Shaposhnykov K. S. et. al. Kherson: Vydavnychyi dim «Helvetyka», 2013. P. 56-58.

17. Lysenko N. O., Biloshkurska N. V. Zastosuvannia vyrobnychoi funktsii Tinbergena pry analizi innovatsiinoi skladovoi ekonomichnoi bezpeky pidpryiemstv APK // Innovatsiina ekonomika. 2012. Issue 4 (30). P. 140-144.

18. Biloshkurska N. V., Biloshkurskyi M. V., Omelyanenko V. A. Evaluation of Ukrainian industry innovative development with a technological progress parameter // Scientific Bulletin of Polissia. 2018. Vol. 2, Issue 1 (13). P. 23-28. doi: http:// doi.org/10.25140/2410-9576-2018-2-1(13)-23-28
19. Tinbergen J. Zur Theorie der Langfristigen Wirtschaftsentwicklung // Weltwirtschaftliches Archiv. 1942. Vol. 55. P. 511-549.

20. Solow R. M. Technical Change and the Aggregate Production Function // The Review of Economics and Statistics. 1957 Vol. 39, Issue 3. P. 312-320. doi: http://doi.org/10.2307/1926047

21. Moroney J. R. Ferguson C. E. Efficient Estimation of Neoclassical Parameters of Substitution and Biased Technological Progress // Southern Economic Journal. 1970. Vol. 37, Issue 2. P. 125-131. doi: http://doi.org/10.2307/1056121

22. Biloshkurska N. V., Biloshkurskyi M. V. Prohnozuvannia rozvytku promyslovoho vyrobnytstva Ukrainy z urakhuvanniam vplyvu tekhnolohichnoho prohresu: proceedings // Priorytety rozvytku natsionalnoi ekonomiky Ukrainy: stratehiia i perspektyvy. Uman: VPTs «Vizavi», 2015. P. 6-8.

23. Tinbergen J. Exhaustion and technological development: A macro-dynamic policy model // Zeitschrift Für Nationalökonomie. 1973. Vol. 33, Issue 3-4. P. 213-234. doi: http://doi. org/10.1007/bf01283657

24. Solow R. M. A Contribution to the Theory of Economic Growth // The Quarterly Journal of Economics. 1956. Vol. 70 , Issue 1. P. 65-94. doi: http://doi.org/10.2307/1884513

25. Cobb C. B., Douglas P. H. A theory of production // The American Economic Review. 1928. Vol. 18, Issue 1. P. 139-165.

26. Biloshkurska N. V. Management of industrial production in Ukraine: innovative aspect // Ekonomichnyi prostir. 2015. Issue 98. P. 54-63

27. Free and open access to global development data. World Bank Open Data. URL: https://data.worldbank.org

Biloshkurska Nataliia, PhD, Associate Professor, Department of Marketing, Management and Business Management, Pavlo Tychyna Uman State Pedagogical University, Ukraine, e-mail: nickbrown@ukr.net, ORCID: http://orcid.org/0000-0002-7617-7836

Biloshkurskyi Mykola, PhD, Associate Professor, Department of Finance, Accounting and Economic Security, Pavlo Tychyna Uman State Pedagogical University, Ukraine, e-mail: nickbrown946@gmail.com, ORCID: http://orcid.org/0000-0002-2826-3983

Chyrva Hanna, PhD, Associate Professor, Department of Economics and Social-Behavioral Sciences, Pavlo Tychyna Uman State Pedagogical University, Ukraine, e-mail: ch56@i.ua, ORCID: http://orcid.org/ 0000-0001-5055-2645 